\title{
PERIZINAN DAN PELANGGARAN SANTRI BERBASIS SMS GATEWAY DENGAN PYTHON DAN GAMMU
}

\author{
FARIS MUSHLIHUL AMIN ${ }^{1)}$, MOCHAMMAD FAID ${ }^{2)}$ \\ FAKULTAS SAINTEK UIN SUNAN AMPEL ${ }^{1}{ }^{1}$, STT NURUL JADID ${ }^{2)}$ \\ e-mail: farismenk@gmail.com ${ }^{1)}$, $\underline{\text { ahmad.faid08@ gmail.com }}^{2)}$
}

\begin{abstract}
Abstrak
Pondok Pesantren adalah model pendidikan pertama dan tertua di Indonesia. Keberadaannya mengilhami model dan sistem-sistem yang ditemukan saat ini, Dari sinilah timbul beberapa permasalahan yaitu, pada saat adanya bertambahnya jumlah santri, permasalahn perijinan, serta data kasus-kasus yang di perbuat oleh santri. Kebutuhan sistem informasi yang semakin luas dan volume pengolahan data semakin meningkat, serta pemberitahuan informasi kepada wali santri sangat penting maka sistem informasi perkembangan ini tidaklah cukup menggunakan system informasi manual. Untuk melengkapi penelitian ini menggunakan metodologi penelitian yang banyak didapat dari berbagai sumber, diantaranya metode observasi langsung ke lapangan, studi literatut, analisis sistem, maupun bersumber dari buku. Perangkat lunak (Software) komputer yang digunakan dalam rancangan dan desain sistem informasi santri Berbasis SMS Gateway di PP. Nurul Jadid Paiton adalah pemrograman Python 2.5 dengan basis data yang dibuat dari MySQL yang sudah jadi paket dengan XAMPP. Dan Juga membutuhkan Modem GSM sebagai pengganti HP untuk memberikan informasi kepada wali santri.
\end{abstract}

Kata Kunci: SMS Gateway, Gammu, dan Python

\section{Abstract}

Boarding is the first and oldest educational model in Indonesia. Its existence is inspired models and systems are found today, is where some of the problems that arise, when the increasing number of students, issues of licensing, as well as data on the cases done by the students. Information system needs an increasingly broad and ever increasing volumes of data processing, as well as the notification of information to parents of students is very important that the development of information systems is not enough to use the system information manually. To complete this study using the research methodology that is obtained from various sources, including direct observation method to the field, literatut studies, systems analysis, and based on the book. Software (Software) computers used in the design and information system design students based SMS Gateway in PP. Nurul Jadid Paiton is Python 2.5 with databases created from MySQL finished with XAMPP package. And also requires a GSM modem as a replacement for HP to provide information to parents of students.

Keywords:up to 5 keywords, separated by commas.

\section{PENDAHULUAN}

Dengan perkembangan pesantren yang cukup pesat banyak masyarakat yang berkeinginan untuk memondokkan putra-putrinya dengan tujuan agar putra-putrinya menjadi orang yang taat kepada agama dan juga menguasai bidang yang ditekuni di Pesantren termasuk bidang teknologi. Namun dalam hal ini orang tua wali harus tetap mengawasi anaknya demi terwujudnya tujuan tersebut.

Dengan semakin banyak masyarakat yang ingin memondokkan anaknya ke Pondok
Pesantren maka disana timbul masalah yang harus dipecahkan bersama-sama, masalah yang pertama adalah wali santri tidak mengetahui keadaan anaknya, seperti anaknya izin keluar Pesantren atau sedang bermasalah dipondok karena melanggar peraturan pesantren, Masalah kedua adalah pihak pengasuh pesantren tidak mengetahui perkembangan santrinya jika santrinya sudah mencapai ribuan orang.

Salah satu teknologi yang bisa dijangkau oleh masyarakat luas adalah telepon seluler, semua orang bisa menggunakannya denga mudah, apalagi dengan harga yang sangat terjangkau hampir semua lapisan masyarakat memiliki dan 
juga mengenal telepon seluler[1]. Penulis bermaksud untuk memanfaatkan teknologi telepon seluler atau hp, untuk memberitahu keadaan anaknya dengan menggunakan SMS Gateway (software yang digunakan untuk membaca SMS atau mengirim SMS melalui modem/hp) kepada pihak wali santri dan pengasuh pesantren. Dalam penelitian ini penulis mengambil Objek Pondok Pesantren Nurul Jadid, di Pondok Pesantren Nurul Jadid, Di Pondok Pesantren Nurul Jadid sudah ada sistem Informasi untuk pendataan santri, namun disana belum ada sistem informasi perizinan, dan pelanggaran santri yang berbasis SMS Gateway[5]

\section{METODE PENELITIAN}

Setelah diketahui komponen Perizinan dan pelanggaran yang ditetapkan, maka perlu dirumuskan hubungan antar komponen tersebut sehingga membentuk suatu hubungan sistematik untuk mencapai tujuan sistem. Dalam membentuk hubungan sistem yang baik perlu dilakukan analisa sistem terlebih dahulu. Perangkat yang akan digunakan dalam menganalisa sistem yaitu Sistem Flow Chart, Data Flow Diagram, dan Entity Relationship Diagram[4].

\subsection{Data Flow Diagram}

Data memiliki peran yang sangat penting dalam sebuah sistem informasi karena merupakan sumber yang akan diolah untuk dijadikan suatu informasi. Dalam suatu sistem alur data berhubungan dengan entitas, proses, dan data storage. Alur data tersebut digambarkan pada Data Flow Diagram dengan beberapa level untuk mempermudah dalam pemahamannya.[4]

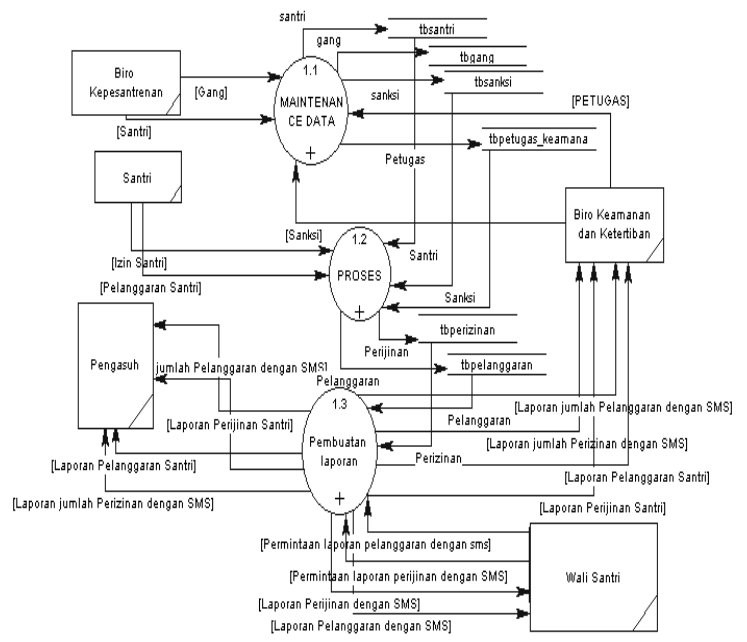

\subsection{Sistem Flow Chart}

Sistem Flow Chart adalah gambar bagan yang menunjukkan alur prosedur sistem secara logika menggambarkan hubungan sistem informasi dengan entitas-entitas yang berhubungan secara global. Bagan ini juga digunakan sebagai alat bantu komunikasi dan dokumentasi. Gambar sistem flowchart dari sistem informasi perizinan dan pelanggaran ini adalah sebagai berikut:

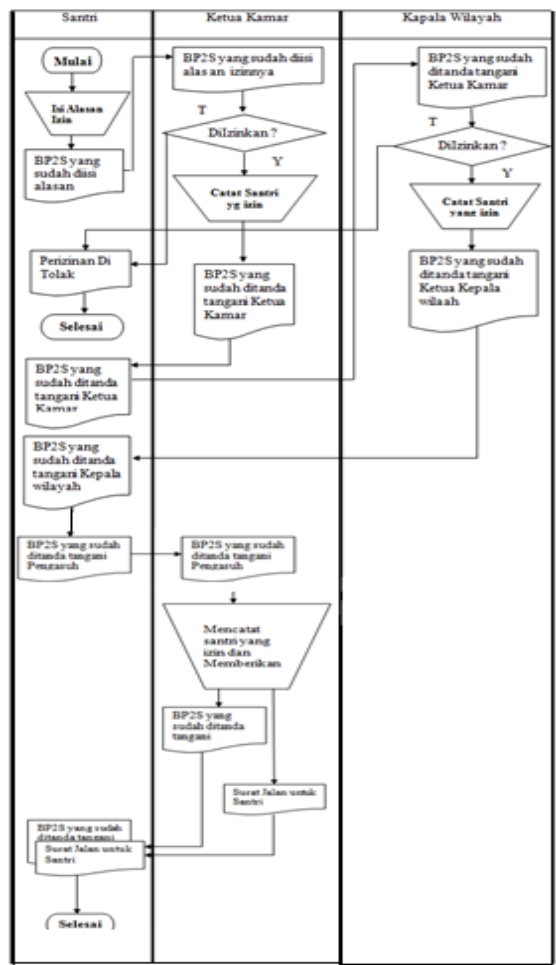

Gambar 2. Flow Chart Perizinan

\subsection{Entity Relationship Diagram}

Sistem informasi terdiri dari beberapa entitas yang merupakan komponen dasar dari suatu sistem. Entitas-entitas yang ada tersebut saling mendukung dan memiliki keterkaitan satu dengan yang lain[4]. Cara menggambarkan hubungan antar entitas adalah dengan menggunakan entity relationship diagram.

Entity relationship diagram merupakan salah satu media untuk menganalisa data dengan menggambarkan pola hubungan antar entitas yang membentuk kerangka system. pada sistem informasi Santri ini entity relationship diagramnya sebagai berikut:

Gambar 1. dfd Level Satu 


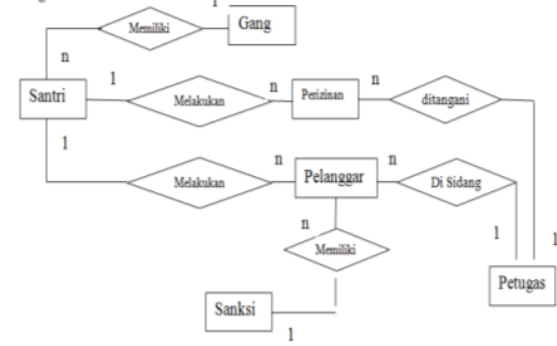

Gambar 3. ERD

Kamus data:

Santri

Petugas

Sanksi

Perizinan

: $\{$ NIS, Nama, Gender, Tmpt_Lahir, Tgl_Lahir, Pendidikan_Terakhir, Masuk_Sekolah, Alamat, Desa, Kecamatan, Kabupaten, Propinsi, Kodepos, Telephone, Nama_Ayah, Nama_Ibu, Pendidikan_Ayah, Pendidikan_Ibu, Pekerjaan_Ayah, Pekerjaan_Ibu, Alamat_w, Desa_w, Kec_w, Kab_w, Prop_w, Kodepos_w, Telp_w, Tgl_Masuk, Tahun, Status, Id Gang

\{ Id_Gang, Nama_Gang

\{ kode_Nama, Jabatan,Password \}

$\{\underline{\mathrm{kd}}$, pelanggaran, jenis, sanksi $\}$

$\{$ NIS, Tanggal, Nama, Alasan,

Tujuan, Lama, Waktu,

Jenis,Kode,Petugas \}

Pelanggaran \{ NIS, Tanggal, Nama, Jenis, Sanksi, Kronologi, pelanggaran,Kode,Petugas

\section{HASIL DAN PEMBAHASAN}

Program Sistem Informasi Santri ini dibuat untuk melengkapi sistem informasi santri yang sudah ada di Pondok Pesantren Nurul Jadid dalam hal perizinan dan pelanggaran santri yang berbasis Sms gateway, dengan kata lain program aplikasi ini dibuat sebagai bahan pertimbangan bagi para pengurus pesantren dan wali santri dalam mengambil keputusan untuk permasalahan perizinan dan pelanggaran yang terjadi di Pondok Pesantren Nurul jadid.

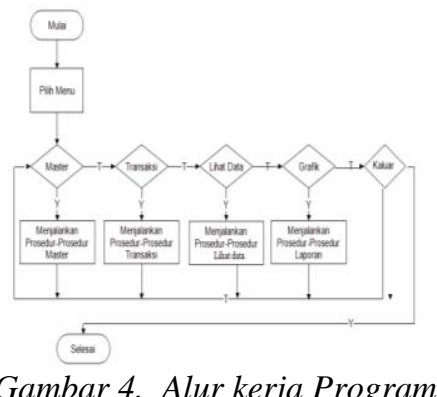

Setelah menyimpan perizinan santri maka sistem akan secara otomatis mengirimkan laporan perizinan berupa sms kepada wali santri yang bersangkutan

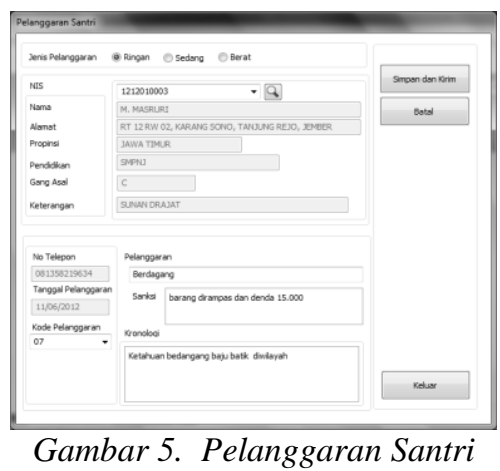

Auto Respon Merupakan Bagian dari SMS Gateway yang mana sistem yang dibuat akan membalas SMS secara otomatis sesuai dengan format yang disetting[5]. Sistem Informasi Santri ini juga dilengkapi dengan auto Respon, adapun Format dari Auto Responnya Sebagai Berikut :

1. NJ DAFTAR (No Induk Santri) Fungsinya adalah untuk mendaftarkan No wali santri kepada sistem

2. IJIN (No Induk Santri) Fungsinya adalah untuk mengecek ijin tidaknya santri hari ini

3. LIHAT IJIN (No Induk Santri) Fungsinya adalah untuk melihat jumlah ijin santri

4. PELANGGARAN (No Induk Santri) Fungsinya adalah untuk melihat jumlah pelanggaran santri.

\section{KESIMPULAN}

Dari analisa yang telah dilakukan dapat dirumuskan beberapa kesimpulan yang berkaitan dengan Sistem Informasi Santri yang memiliki kelebihan tersendiri dalam pembangunan sistem tersebut yaitu :

1. Sistem Informasi Santri akan sangat membantu pengurus pesantren dan wali santri dalam hal proses perizinan dan pelanggaran santri karena sistem ini memiliki fasilitas sms gateway dan juga tampilan program yang user friendly, sehingga program aplikasi akan lebih interaktif dan mengutamakan kenyamanan dalam menjalankannya. 
2. Untuk pencapaian hasil yang tepat diperlukan proses yang sesuai dengan model dan aturan yang telah ditetapkan dalam BP2S (Buku Pedoman Penghubung Santri).

\section{DAFTAR PUSTAKA}

Journal Article

[1] Andy Dustman,Python and MySQL, Santa Clara : 2005

[2] http://www.ikhwaniril.blogspot.com/2011/05/ membangun-sms-gateway-menggunakangammu.html

[3] Haryanto Bambang, Sistem manajemen Basis Data, Informatika Bandung: 2004

[4] Jogiyanto HM, Analisis dan Desain Sistem Informasi : Pendekatan Terstruktur, Teori dan Praktek Aplikasi Bisnis, ANDI offset Yogyakarta: 2002

[5] Rosihan Ari, Panduan Instalasi Gammu, , http://diveintopython.org/ : 2012 